\title{
Changes of raffinose and stachyose in soy milk fermentation by lactic acid bacteria from local fermented foods of Indonesian
}

\author{
Sumarna* \\ Department of Food Science and Biotechnology,Technical Implementation Unit for Development of Chemical \\ Engineering Processes, Indonesian Institute of Sciences Yogyakarta, Indonesia \\ E-mail:marna smn@yahoo.com
}

Received 30 June 2008; received in revised form 11 September 2008; accepted 11 September 2008

\begin{abstract}
The objective of this study was to evaluate the fermentative characteristics of lactic acid bacteria isolated from local fermented foods and consume raffinose and stachyose during fermentation soymilk. Lactobacillus plantarum pentosus SMN, 01, Lactobacillus casei subsp rhamnosus FNCC, 098, Lactobacillus casei subsp rhamnosus FNCC, 099, Streptococcus thermofilus, 001, Lactobacillus delbrueckii subsp. bulgaricus FNCC, 0045, Lactobacillus plantarum SMN, 25, and Lactobacillus plantarum pentosus FNCC, 235 exhibited variable $\alpha$-galactosidase activity with Lactobacillus plantarum SMN, 25, showing the highest activity in MRS supplemented media. However, all organisms reached the desired therapeutic level $\left(10^{8} \mathrm{cfu} / \mathrm{mL}\right)$ likely due to their ability to metabolize oligosaccharides during fermentation in soymilk at $41^{\circ} \mathrm{C}$. The oligosaccharide metabolism depended on a-galactosidase activity. Lactobacillus plantarum SMN, 25, L. plantarum pentosus SMN, 01 and Lactobacillus plantarum pentosus FNCC, 235 reduced raffinose and stachyose by $81.5,73.0,67.0 \%$, and $78.0,72.5,66.0 \%$ respectively in soymilk.
\end{abstract}

Keywords: Lactobacillus sp, fermentation soymilk, a-galactosidase, raffinose, stachyose

\section{INTRODUCTION}

Soybeans (Glycine max. L. Merr) are a rich source of protein and economical protein food. Soy-based foods may provide a range of health benefits to consumers due to their hypolipidemic, anticholesterolemic and antiatherogenic properties as well as due to reduced allergenicity (Trindade et al., 2001). It also contains isoflavones, which have been linked to reduced risk of most hormone-associated health disorders (Kurzer, 2000). However, consumption of soymilk is hindered due to the presence of unpleasant off-flavors carried over from soy beans. These characteristic flavors are caused by $n$ hexanal and pentanal, which occur in beans as a product of breakdown of unsaturated fatty acids (Arai et al., 1996; Scalabrini et al., 1998). In addition to these aldehydes, soymilk contains various oligosaccharides including raffinose and stachyose that may cause a gastrointestinal discomfort to consumers (Scalabrini et al., 1998; Shin et al., 2000). Raffinose and stachyose are $\alpha$-galactosides of sucrose comprising three and four monomeric units respectively and are non-digestible in the gut due to the absence of $\alpha$-galactosidase in the human intestinal mucosa. Consequently, intact oligosaccharides pass directly into the lower intestine where they are metabolized by bacteria that possess this enzyme, resulting in the production of gases (Tsangalis and Shah, 2004). This problem could be alleviated by using a specific enzyme, a-galactosidase or an organism that possesses high $\alpha$-galactosidase activity to minimize the content of flatulence-causing oligosaccharides in the product (Scalabrini et al., 1998). There has been an alternative approach that utilizes lactic acid bacteria processing á-galactosidase activity which can hydrolysed the raffinose and stachyose during fermentation (Garro et al., 2005). This would provide simple sugar as substrate for the lactic acid bacteria as well as reduce the level of raffinose and stachyose. Some researchers (Bordignon et al., 2004) have reported the lactic acid bacteria fermentation would be a promising way, because some lactic acid bacteria are effective to reduce the off-flavour. Others researchers (Mital and Steinkraus, 1975; Pinthong et al., 1980; Garro et al., 1983) have reported the reduction of raffinose and stachyose during fermentation of soymilk using pure or mixed culture of following bacteria: Lactobacillus cellobiosis, $L$. plantarum, $L$. fermentum, L. delbrueckii, L. fermenti, L. pentosaceus and L. bulgaricus, Streptococcus thermofilus. Several Bifidobacterium strains have been reported to produce varying levels of $\alpha$-galactosidase, which metabolized $\alpha$ galactosyl oligosaccharides in soymilk (Scalabrini et al., 1998). Soymilk is a good medium for growing Bifidobacterium because it contains oligosaccharides that are fermented by most of the strains belonging to this genus (Liu, 1997; Scalabrini et al., 1998). Bifidobacterium sp., Lactobacillus acidophilus, and $L$. casei have been associated with health-promoting effects and are classified as probiotic organisms since they are thought to improve the microbial balance in the human gastrointestinal tract (Schrezenmeir and De Vrese, 2001). Health benefits attributed to probiotics include antimicrobial, antimutagenic, anticarcinogenic and antihypertensive properties (Lourens-Hattingh and Viljoen, 2001). The ability of lactic acid bacteria to ferment the

\footnotetext{
Corresponding author
} 
available carbohydrates in a growing medium varies with strains. Matsuoka et al. (1968) found that $S$. thermophilus produced a greater amount of acid in soymilk than Lactococcus lactis and L. delbrueckii ssp. bulgaricus. Mital et al. (1974) also reported that certain organisms such as $S$. thermophilus, $L$. acidophilus, $L$. cellobiosis and $L$. plantarum which utilize sucrose, exhibited significant growth and produced substantial amounts of acid in soymilk. Others such as L. delbrueckii ssp. bulgaricus grew poorly in soymilk because of their inability to ferment sucrose and other carbohydrates in soymilk. The use of lactic acid bacteria in preparing fermented soy products has received much attention (Lee et al., 1990; Cheng et al., 1990; Karleskind et al., 1991; Sherkat et al., 2001). Several studies on $\alpha$-galactosidase activity and metabolism of a-galactosyl oligosaccharides by Bifidobacterium strains in soymilk have been reported but there is a lack of detailed information in the literature about the behavior of probiotic organisms ( $L$. acidophilus and $L$. casel) and their importance as a part of the starter cultures for making fermented soy products. The objective of this study was to evaluate the fermentative characteristics of lactic acid bacteria isolated from local fermented foods and consume raffinose and stachyose during fermentation soymilk

\section{MATERIAL AND METHODS}

Soybeans (Glycine max. L. Merr) of cultivar wilis were obtained from Gading, Playen, Gunungkidul in Yogyakarta. High-performance liquid chromatography (HPLC, Hitachi, Japan). Raffinose and stachyose standards were purchased from Sigma (Merck, oxoid). All other chemicals and reagents were of analytical grade.

\section{Strains and culture conditions}

Seven strains of lactic acid bacteria were isolated from local fermented foods such as cassava fermented (gatot), bamboo shoot, moroni ketchup, yoghurt. Lactobacillus plantarum pentosus SMN, 01, L. casei subsp rhamnosus FNCC, 098, L. casei subsp rhamnosus FNCC, 099, Streptococcus thermofilus, 001, Lactobacillus delbrueckil subsp. bulgaricus FNCC, 0045, L. plantarum SMN, 25 , and L. plantarum pentosus FNCC, 235 were obtained from food and nutrition culture collection of Centre for Food and Nutrition studies, Gadjah Mada University. Culture stock were kept in $10 \%$ glycerol and $10 \%$ skim milk with the ratio $1: 1$, kept in sterile $1,5 \mathrm{ml}$ polyethylene srew cap tubles, at $-40^{\circ} \mathrm{C}$. The strains were rejuvenated in MRS broth (Merck, Oxoid) at $37^{\circ} \mathrm{C}$ for $24 \mathrm{~h}$.

\section{Soymilk preparation}

Soybean grains $(500 \mathrm{~g})$ were soaked in cold water for 12 $\mathrm{h}$ at room temperature $\left(27^{\circ} \mathrm{C}\right)$. After soaking, water was discarded and the grains were then ground in a blender, for three minutes, in $4000 \mathrm{~mL}$ of hot water at $60{ }^{\circ} \mathrm{C}$. Soymilk was extracted by filtration through a cotton cloth.
The slurry was cooked for ten minutes, filtered and boiled at $70{ }^{\circ} \mathrm{C}$ for 30 minute.

\section{Extraction of crude $\alpha$-galactosidase}

One of the requirements for good growth of cultures in soymilk media is the activity of a-galactosidase. All organisms (L. plantarum pentosus SMN, 01, L. casei subsp rhamnosus FNCC, 098 L. casei subsp rhamnosus FNCC, 099, Streptococcus thermofilus, 001, L. delbrueckii subsp. bulgaricus FNCC, 0045, L. plantarum $S M N, 25$, and L. plantarum pentosus FNCC, 235) were assessed for $\alpha$-galactosidase activity according to the methods of Scalabrini et al. (1998) and Tsangalis and Shah (2004). In order to ascertain the metabolic characteristics of $L$. plantarum pentosus SMN, 01, $L$. casei subsp rhamnosus FNCC, 098 L. casei subsp rhamnosus FNCC, 099, Streptococcus thermofilus, 001, $L$. delbrueckii subsp. bulgaricus FNCC, 0045, $L$. plantarum SMN, 25, and L. plantarum pentosus FNCC, 235 in soymilk, a-galactosidase activity was examined in MRS basal broth supplemented with $2 \%(\mathrm{w} / \mathrm{v})$ glucose, $2 \%(\mathrm{w} / \mathrm{v})$ raffinose or a mixture of $1 \%(\mathrm{w} / \mathrm{v})$ each of raffinose and glucose. During fermentation, $50 \mathrm{~mL}$ aliquots were withdrawn aseptically at $6,12,18,24$, and $30 \mathrm{~h}$ and stored at $4{ }^{\circ} \mathrm{C}$. Bacterial cells were harvested by centrifuging at $4000 \times \mathrm{g}$ for $10 \mathrm{~min}$ at $4^{\circ} \mathrm{C}$ using a refrigerated centrifuge. The cell pellet was washed in 20 $\mathrm{mL}$ cold $50 \mathrm{mM}$ sodium citrate buffer ( $\mathrm{pH} 5.5)$ and centrifuged at $4000 \times \mathrm{g}$ for $10 \mathrm{~min}$ and this was repeated twice. Finally cells were resuspended in $10 \mathrm{~mL}$ of the same buffer, placed in an ice bath and sonicated three times for $5 \mathrm{~min}$. The cell debris was removed by centrifugation at $10,000 \times g$ for $30 \mathrm{~min}$ at $4{ }^{\circ} \mathrm{C}$. The supernatant was used as a crude enzyme extract.

\section{Assay for $\alpha$-galactosidase}

Crude enzyme extracts from the organisms were assayed for $\alpha$-galactosidase activity according to the method of Scalabrini et al. (1998). Briefly, $250 \mu \mathrm{L}$ of crude enzyme extract was mixed with $500 \mu \mathrm{L}$ of $5 \mathrm{mM} \mathrm{p}$-nitrophenyl- $\alpha-\mathrm{D}$ galactopyranoside ( $p N P G)$ and incubated at $37{ }^{\circ} \mathrm{C}$ for 30 min. The reaction was stopped by addition of $500 \mu \mathrm{L}$ of cold $0.2 \mathrm{M}$ sodium carbonate. The $\alpha$-galactosidase activity was determined by the rate of hydrolysis of pNPG. The amount of $p$-nitrophenol released was measured with a spectrophotometer at $420 \mathrm{~nm}$. One unit of enzyme activity was defined as the amount of enzyme that released 1 $\mu \mathrm{mol}$ of $p$-nitrophenol from $p N P G$ per millilitre per min under assay conditions. The specific activity was expressed as units $(U)$ of $\alpha$-galactosidase activity per milligram of protein.

\section{Fermentation of soymilk}

Eight batches of $250 \mathrm{~mL}$ of soymilk were heat treated $\left(100{ }^{\circ} \mathrm{C}\right.$ for $\left.30 \mathrm{~min}\right)$ and aseptically inoculated with $1 \%(\mathrm{v} / \mathrm{v})$ of each culture and incubated at $41{ }^{\circ} \mathrm{C}$ for $48 \mathrm{~h}$. All fermentations were performed in triplicate. A control 
consisted of uninoculated soymilk. During fermentation, aliquots from each batch were taken at $0,6,12,18,24$, and $30 \mathrm{~h}$ to monitor cell growth, $\mathrm{pH}$ changes, organic acids production, and metabolism of oligosaccharides activities.

\section{Cell Growth}

The cell growth of each organism was assessed by enumerating bacterial population during $30 \mathrm{~h}$ of fermentation in soymilk as described in the procedure determination of viability The colony counts of $L$. plantarum pentosus SMN, 01, L. casei subsp rhamnosus FNCC, 098, L. casei subsp rhamnosus FNCC, 099, Streptococcus thermofilus, 001, Lactobacillus delbrueckii subsp. bulgaricus FNCC, 0045, L. plantarum SMN, 25, and $L$. plantarum pentosus FNCC, 235 were determined as described previously (Dave and Shah, 1996; Tharmaraj and Shah, 2003). The media that were selected as suitable for the viability studies included MRS agar (Sigma Jakarta, Indonesia) and aerobic incubation at $41^{\circ} \mathrm{C}$ for 30 h for strains $L$. plantarum pentosus SMN, 01, L. casei subsp rhamnosus FNCC, 098, L. casei subsp rhamnosus FNCC, 099, Streptococcus thermofilus, 001, L. delbrueckii subsp. bulgaricus FNCC, 0045, L. plantarum $S M N, 25$, and $L$. plantarum pentosus FNCC, 235 . The incubation was performed at $41^{\circ} \mathrm{C}$ anaerobically for $30 \mathrm{~h}$ for all cultures (Laroia and Martin, 1991; Dave and Shah, 1996; Ravula and Shah 1998; Tharmaraj and Shah, 2003).

\section{$\mathrm{pH}$ changes and production of organic acids}

During culture growth, the main metabolic products are organic acids, particularly lactic and acetic acids. The $\mathrm{pH}$ changes in batches of soymilk were monitored during fermentation at $0,6,12,18,24$ and $30 \mathrm{~h}$ using a $\mathrm{pH}$ meter (HANNA instruments 8417, Singapore).

\section{Determination of organic acids}

Determination of organic acids was carried out according to Shah and Ravula (2000). Briefly, $3 \mathrm{~mL}$ yoghurt samples were mixed with $50 \mu \mathrm{L}$ of $15.5 \mathrm{M}$ nitric and $1.0 \mathrm{~mL}$ of 0.01 $\mathrm{M}$ sulfuric acids. The resulting mixture was centrifuged at $14,000 \times g$ for $30 \mathrm{~min}$ using an Eppendorf $5415 \mathrm{C}$ centrifuge for removal of proteins. The supernatant was filtered through a $0.20 \mu \mathrm{m}$ membrane filter into an HPLC vial. The separation of organic acids was achieved using a Varian HPLC fitted with an Aminex HPX - 87H, $300 \times 7.8$ $\mathrm{mm}$ ion exchange column (Biorad Life Science Group, Hercules, USA) and a guard column maintained at $65^{\circ} \mathrm{C}$. The mobile phase was $0.01 \mathrm{M} \mathrm{H} 2 \mathrm{~S} 04$ with a flow rate of $0.6 \mathrm{~mL} / \mathrm{min}$. Quantification of acetic and lactic acids were performed from the standard curves obtained using solutions of pre-determined concentrations.

\section{Determination of oligosaccharides}

The extraction of sugars from fermented and unfermented soymilk samples was performed using the method described previously by Scalabrini et al. (1998) with some modifications. Briefly, $3 \mathrm{~mL}$ aliquots were centrifuged at $14,000 \times g$ for $30 \mathrm{~min}$ for protein removal, followed by filtration using a $0.20 \mu \mathrm{m}$ membrane filter. The concentration of raffinose, stachyose and sucrose was determined with a Varian HPLC fitted with an Alltima amino column $(250 \times 4.6 \mathrm{~mm} \times 5 \mu \mathrm{m} 100 \AA)$ and corresponding guard column maintained at $30{ }^{\circ} \mathrm{C}$ and an $\mathrm{RI}$ detector (ERC-7515A, ERMA Cr. Inc., Kawaguchi City, Japan). The mobile phase consisted of $75 \%$ acetonitrile and $25 \%$ distilled water and was maintained at a flow rate of $1 \mathrm{~mL} / \mathrm{min}$ isocratically. A $20 \mu \mathrm{L}$ injection volume was used for both samples and standards. The retention times of the standards for raffinose, stachyose and sucrose (Sigma) were at $11.4,19.1$ and $7.8 \mathrm{~min}$, respectively. Standard stock solutions of raffinose $(2.53 \mathrm{~g} / 100 \mathrm{~mL})$, stachyose $(2.03 \mathrm{~g} / 100 \mathrm{~mL})$ and sucrose $(2.53 \mathrm{~g} / 100 \mathrm{~mL})$ were used for preparation of standard calibration curve. The concentration of oligosaccharides was derived from the standard curve and was expressed as milligram of sugar per $100 \mathrm{~mL}$ of soymilk.

\section{Statistical analysis}

All results obtained were analysed as a split plot in time design using general linear model procedure of the SAS System (SAS, 1996). The univariate ANOVA test was validated by fulfilling Huynh-Feldt $(\mathrm{H}-\mathrm{F})$ condition (Littell et al., 1998). Where appropriate, one-way ANOVA and correlational analysis were employed using Microsoft Excel (Albright et al., 1999) and the multicomparison of means was assessed by Tukey's test. The statistical level of significance was presen at 0.05 .

\section{RESULTS AND DISCUSSION}

\section{Proximate composition and total monosaccharides and oligosaccharides contents of cultivar wilis soybean and soymilk}

Results of analysis proximate composition and total monosaccharides and oligosaccharides contents are given in Table 1. Chromatograms profiles of monosaccharides and oligosaccharides detected using HPLC method from soymilk is shown in Figure 1.

Table 1. Proximate composition wilis soybean $(\mathrm{mg} / 100 \mathrm{~g}$ dry weight) ${ }^{\mathrm{a}}$ and soymilk (mg/100L $)^{\mathrm{a}}$

\begin{tabular}{lcc}
\hline Composition & Will soybeans & soymilk \\
\hline moisture & $11.0 \pm 0.4$ & $88.90 \pm 1.8$ \\
protein & $34.0 \pm 1.0$ & $3.6 \pm 0.1$ \\
fat & $21.6 \pm 0.2$ & $1.3 \pm 0.03$ \\
carbohydrates & $28.1 \pm 1.2$ & $2.08 \pm 0.01$ \\
raffinose $(\mathrm{mg})$ & $5.87 \pm 2.8$ & $3.79 \pm 0.64$ \\
stachyose & & \\
(mg) & $8.75 \pm 1.5$ & $6.17 \pm 0.78$ \\
ash & $2.97 \pm 0.1$ & $0.46 \pm 0.01$ \\
\hline
\end{tabular}

${ }^{a}$ From means standard deviation of three duplicates for each sample 


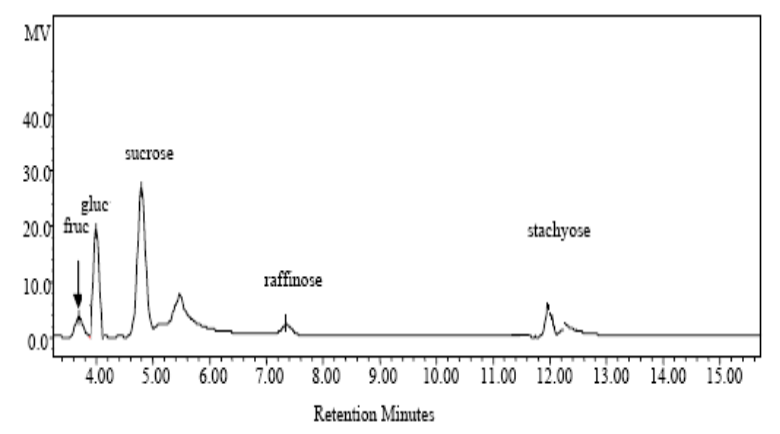

Figure 1. Chromatograms profiles of monosaccharides and oligosaccharides detected using HPLC method from soymilk

\section{a-Galactosidase specific activity of strains lactic acid Bacteria isolated from local fermented foods}

The $\alpha$-galactosidase activity of strains lactic acid Bacteria isolated from local fermented foods is shown in Table 2. The organisms exhibited $\alpha$-galactosidase activity at varying degrees, and fermentation time was a significant $(P<0.05)$ factor for $\alpha$-galactosidase activity during the $30 \mathrm{~h}$ incubation at $41{ }^{\circ} \mathrm{C}$. This might be due to growth differences in the respective media which likely determined the amount of enzymes produced during fermentation. Interestingly, a-galactosidase activity in the medium containing raffinose declined substantially during 12 to $24 \mathrm{~h}$ of fermentation for some organisms but increased significantly $(P<0.05)$ for all microorganisms at $30 \mathrm{~h}$. This followed the growth pattern of the organisms in the medium during the fermentation period. However, $L$. plantarum SMN, 25, grew better than the other organisms in that medium as $\alpha$-galactosidase activity increased significantly $(P<0.05)$ until the end of fermentation. This suggests that $L$. plantarum SMN, 25, may have hydrolyzed raffinose mainly by producing acetate and lactate from the bifidus carbohydrate catabolism pathway. Bordignon et al. (2004) reported strain, L. delbrueckii ssp. bulgaricus showed the lowest $\alpha$-galactosidase activity in the medium containing raffinose (compared to other organisms). Although $\alpha$-galactosidase specific activity in the glucose/raffinose medium was not as high as that of medium containing raffinose, the trend of activity was similar. The presence of glucose in MRS medium, on the other hand, resulted in high a-galactosidase activity for the majority of the organisms in comparison to other media except L. plantarum SMN, 25, in $2 \%$ raffinose. All organisms grew well in MRS medium, which suggests that an increase in $\alpha$-galactosidase is due to an increase in cell density. After reaching the log phase, a-galactosidase activity was reduced $(P<0.05)$. This reduction was most probably a result of depletion of the readily available carbon source or other factors such as accumulation of organic acids drop in $\mathrm{pH}$ and reduction/aging bacteria population (Table 4). The presence of $1 \%$ each of glucose and raffinose did not stimulate $(P>0.05)$ the synthesis of a-galactosidase as much as that containing $2 \%$ raffinose did (Table 2). Mital and Steinkraus (1975) reported that $1 \%$ raffinose supplementation increased the production of a-galactosidase for lactic acid bacteria strains but with little or no effect on the a-galactosidase activity of lactic acid bacteria. Since raffinose is an $\alpha$-galactoside sugar found in soymilk, these selected organisms may grow well in soymilk for manufacture of soy based yoghurt. The effect of raffinose and glucose on the production of organic acids by strains of lactic acid bacteria isolated from local fermented foods (no shows). L. plantarum SMN, 25 , exhibited the highest $(P<0.05)$ acid lactic production in $2 \%$ raffinose medium with significant $(P<0.05)$ increases during fermentation as opposed to other organisms which produced organic acids in comparable quantities $(P>0.05)$. Omogbai et al. (2005) reported that some lactic acid bacteria strains produced relatively low quantities of acetic acid in a modified medium. The production of acetic acid in $1 \%$ raffinose and $1 \%$ glucose by $L$. plantarum pentosus SMN, 01, L. casei subsp rhamnosus FNCC, 098, L. casei subsp rhamnosus FNCC, 099, Streptococcus thermofilus, 001, Lactobacillus delbrueckii subsp. bulgaricus FNCC, 0045, L. plantarum SMN, 25, and L. plantarum pentosus FNCC, 235 showed a slight $(P>0.05)$ variation in concentrations to that produced in the $2 \%$ raffinose. The mixture of glucose/raffinose stimulated higher $(P<0.05)$ production of lactic acid by all organisms studied compared to the medium containing $2 \%$ raffinose. The MRS broth which contained $2 \%$ glucose showed similar production of lactic acid to that of the mixture but low $(\mathrm{P}<0.05)$ production of acetic acid for all the organisms. Our study showed metabolism of raffinose as the sole energy source produced substantial amount of lactic acid.

\section{Sugars metabolism in soymilk}

Tables 3 and 4 show the utilization of raffinose, stachyose and sucrose and the production of lactic acids. The utilization of raffinose and stachyose in soymilk varied and appeared to depend on the a-galactosidase activity of the organism (Table.2). L. plantarum SMN, 25, L. plantarum pentosus SMN, 01 and L. plantarum pentosus FNCC, 235 reduced raffinose significantly $(P<0.05)$ by $78.1 \%, 72.5 \%$ and $66 \%$, respectively, whereas the remaining organisms showed less than $66 \%$ reduction after $24 \mathrm{~h}$. Bordignon et al. (2004) found that lactic acid bacteria strains metabolized raffinose in soymilk, as opposed to yoghurt cultures, which did not reduce raffinose and stachyose during growth in soymilk. Our study was in line with that reported by Bordignon et al. (2004), which showed that raffinose, was substantially metabolized by lactic acid bacteria strains. The organisms in general metabolized stachyose by over $66 \%$ after $24 \mathrm{~h}$, with L. plantarum SMN, 25, and L. plantarum pentosus SMN, 01 showing the highest hydrolysis of $78 \%$ and $72.5 \%$, respectively. Our findings are in line with those of Mital and Steinkraus (1975), who reported that fermentation of soymilk with lactic cultures possessing a-galactosidase activity reduced raffinose and stachyose contents. Overall, the sucrose concentration in soymilk was significantly $(P<0.05)$ 
Table 2. $\alpha$-Galactosidase activity of strains lactic acid Bacteria isolated from local fermented foods in supplemented media at $41^{\circ} \mathrm{C}$ for $30 \mathrm{~h}^{(\mathrm{x})}$

\begin{tabular}{|c|c|c|c|c|}
\hline \multirow{2}{*}{ Strain } & \multirow{2}{*}{$\begin{array}{l}\text { Incubation } \\
\text { time (h) }\end{array}$} & \multicolumn{3}{|c|}{ a-galactosidase specific activity(U/mg) } \\
\hline & & raffinose & raff + gluc & glucose \\
\hline \multirow[t]{6}{*}{ L. casei subsp rhamnosus FNCC, 098} & 0 & $5.02 \pm 1.04^{\mathrm{a}}$ & $6.89 \pm 1.24^{\mathrm{a}}$ & $12.65 \pm 0.44^{a}$ \\
\hline & 6 & $5.18 \pm 1.05^{\mathrm{b}}$ & $7.01 \pm 1.14^{\mathrm{a}}$ & $12.36 \pm 0.45^{\mathrm{a}}$ \\
\hline & 12 & $5.32 \pm 1.10^{\mathrm{C}}$ & $7.43 \pm 1.04^{c}$ & $13.49 \pm 0.24^{b}$ \\
\hline & 18 & $5.57 \pm 1.05^{d}$ & $7.65 \pm 1.05^{d}$ & $14.37 \pm 0.45^{\mathrm{c}}$ \\
\hline & 24 & $7.02 \pm 1.11^{d}$ & $9.35 \pm 1.11^{d}$ & $14.65 \pm 0.34^{d}$ \\
\hline & 30 & $6.72 \pm 1.45^{\mathrm{e}}$ & $9.27 \pm 1.15^{\mathrm{d}}$ & $14.68 \pm 0.35^{d}$ \\
\hline \multirow[t]{6}{*}{ L. plantarum SMN, 25} & 0 & $11.27 \pm 0.45^{\mathrm{a}}$ & $14.21 \pm 1.23^{\mathrm{a}}$ & $13.62 \pm 0.44^{\mathrm{a}}$ \\
\hline & 6 & $17.20 \pm 1.11^{\mathrm{b}}$ & $16.7 \pm 1.14^{\mathrm{b}}$ & $17.69 \pm 0.45^{b}$ \\
\hline & 12 & $25.12 \pm 1.04^{\mathrm{c}}$ & $17.4 \pm 1.04^{\mathrm{c}}$ & $23.48 \pm 0.24^{\mathrm{C}}$ \\
\hline & 18 & $65.78 \pm 1.45^{d}$ & $19.53 \pm 1.05^{d}$ & $36.16 \pm 0.75^{d}$ \\
\hline & 24 & $98.66 \pm 2.14^{\mathrm{e}}$ & $27.22 \pm 1.16^{\mathrm{e}}$ & $43.81 \pm 0.34^{e}$ \\
\hline & 30 & $100.87 \pm 2.45^{\dagger}$ & $28.17 \pm 1.15^{\dagger}$ & $43.89 \pm 0.65^{\mathrm{e}}$ \\
\hline \multirow[t]{6}{*}{ L. delbrueckii subsp. Delbrueckii FNCC, 045} & 0 & $5.02 \pm 0.15^{\mathrm{a}}$ & $6.89 \pm 1.24^{\mathrm{a}}$ & $12.65 \pm 0.44^{\mathrm{a}}$ \\
\hline & 6 & $5.18 \pm 0.14^{a}$ & $7.21 \pm 1.14^{\mathrm{a}}$ & $12.36 \pm 0.45^{\mathrm{a}}$ \\
\hline & 12 & $5.32 \pm 0.32 a$ & $7.43 \pm 1.04^{\mathrm{a}}$ & $13.49 \pm 0.24^{b}$ \\
\hline & 18 & $5.57 \pm 0.74^{b}$ & $7.65 \pm 1.05^{\mathrm{b}}$ & $14.37 \pm 0.45^{b}$ \\
\hline & 24 & $7.02 \pm 0.41^{\mathrm{c}}$ & $9.35 \pm 1.11^{\mathrm{c}}$ & $14.65 \pm 0.34^{\mathrm{C}}$ \\
\hline & 30 & $6.72 \pm 0.45^{\mathrm{c}}$ & $9.27 \pm 1.15^{\mathrm{C}}$ & $14.68 \pm 0.35^{\mathrm{C}}$ \\
\hline \multirow[t]{6}{*}{ Streptococcus thermofilus, 001} & 0 & $5.02 \pm 0.15^{\mathrm{a}}$ & $6.89 \pm 1.24^{a}$ & $12.65 \pm 0.44^{\mathrm{a}}$ \\
\hline & 6 & $11.18 \pm 1.45^{\mathrm{b}}$ & $7.21 \pm 1.16^{\mathrm{b}}$ & $16.36 \pm 0.45^{b}$ \\
\hline & 12 & $18.32 \pm 1.45^{\mathrm{c}}$ & $7.43 \pm 1.04^{b}$ & $23.49 \pm 0.44^{\mathrm{C}}$ \\
\hline & 18 & $26.21 \pm 1.45^{d}$ & $17.57 \pm 1.05^{\mathrm{c}}$ & $30.68 \pm 0.45^{d}$ \\
\hline & 24 & $38.13 \pm 1.45^{\mathrm{e}}$ & $27.29 \pm 1.10^{\mathrm{e}}$ & $38.19 \pm 0.34^{\mathrm{e}}$ \\
\hline & 30 & $40.31 \pm 1.45^{f}$ & $27.74 \pm 1.15^{\mathrm{e}}$ & $38.85 \pm 0.35^{\mathrm{e}}$ \\
\hline \multirow[t]{6}{*}{ L. plantarum pentosus SMN, 01} & 0 & $10.02 \pm 1.12^{\mathrm{a}}$ & $6.89 \pm 1.24^{\mathrm{a}}$ & $12.65 \pm 0.44^{\mathrm{a}}$ \\
\hline & 6 & $16.18 \pm 1.45^{\mathrm{b}}$ & $7.25 \pm 1.14^{b}$ & $15.36 \pm 0.45^{b}$ \\
\hline & 12 & $22.32 \pm 1.04^{\mathrm{c}}$ & $7.43 \pm 1.04^{b}$ & $23.49 \pm 0.24^{\mathrm{C}}$ \\
\hline & 18 & $36.21 \pm 1.45^{d}$ & $17.57 \pm 1.05^{\mathrm{c}}$ & $33.68 \pm 0.45^{d}$ \\
\hline & 24 & $88.13 \pm 1.14^{\mathrm{e}}$ & $27.29 \pm 1.09^{d}$ & $43.19 \pm 0.74^{\mathrm{e}}$ \\
\hline & 30 & $90.31 \pm 1.45^{f}$ & $27.74 \pm 1.15^{d}$ & $43.85 \pm 0.35^{\mathrm{e}}$ \\
\hline \multirow[t]{6}{*}{ L. plantarum pentosus FNCC, 235} & 0 & $9.02 \pm 1.00^{\mathrm{a}}$ & $6.89 \pm 1.24^{\mathrm{a}}$ & $12.65 \pm 0.44^{a}$ \\
\hline & 6 & $12.18 \pm 1.04^{b}$ & $7.21 \pm 1.14^{\mathrm{a}}$ & $15.36 \pm 0.45^{b}$ \\
\hline & 12 & $18.32 \pm 1.45^{\mathrm{c}}$ & $7.43 \pm 1.04^{\mathrm{a}}$ & $23.49 \pm 0.24^{\mathrm{C}}$ \\
\hline & 18 & $26.61 \pm 1.05^{d}$ & $17.57 \pm 1.05^{\mathrm{b}}$ & $33.68 \pm 0.45^{d}$ \\
\hline & 24 & $38.13 \pm 1.45^{\mathrm{e}}$ & $27.29 \pm 1.11^{c}$ & $44.19 \pm 0.34^{e}$ \\
\hline & 30 & $40.81 \pm 1.14^{f}$ & $27.74 \pm 1.15^{\mathrm{c}}$ & $43.85 \pm 0.35^{\mathrm{e}}$ \\
\hline \multirow[t]{6}{*}{ L. casei subsp rhamnosus FNCC, 099} & 0 & $5.02 \pm 1.05^{\mathrm{a}}$ & $6.89 \pm 1.24^{\mathrm{a}}$ & $12.65 \pm 0.41^{a}$ \\
\hline & 6 & $5.18 \pm 1.04^{\mathrm{a}}$ & $7.21 \pm 1.14^{\mathrm{a}}$ & $12.36 \pm 0.45^{\mathrm{a}}$ \\
\hline & 12 & $5.32 \pm 1.05^{\mathrm{a}}$ & $7.43 \pm 1.04^{\mathrm{a}}$ & $13.49 \pm 0.24^{\mathrm{a}}$ \\
\hline & 18 & $5.57 \pm 1.14^{\mathrm{b}}$ & $7.65 \pm 1.05^{b}$ & $14.37 \pm 0.45^{b}$ \\
\hline & 24 & $7.02 \pm 1.10^{\mathrm{C}}$ & $9.35 \pm 1.11^{\mathrm{c}}$ & $14.65 \pm 0.34^{b}$ \\
\hline & 30 & $6.72 \pm 1.15^{\mathrm{c}}$ & $9.27 \pm 1.15^{\mathrm{c}}$ & $14.68 \pm 0.35^{b}$ \\
\hline
\end{tabular}

${ }^{(\mathrm{X})}$ From means \pm standard deviation of three duplicates for each sample.

${ }^{a b c d e f}$ Means in the same column for particular strains with different small letter superscripts are significantly different.

One unit of enzyme was defined as the amount of enzyme required to release $1 \mu \mathrm{mol}$ of $p$-nitrophenol from $p$ nitrophenyl- $\alpha$-D-galactopyranoside per $\mathrm{mL}$ per min under assay, Significant when $\mathrm{P}<0.05$ 
Table 3 Changes in concentration of raffinose, stachyose and sucrose in soymilk during fermentation with strains lactic acid Bacteria isolated from local fermented foods for $0,6,12,18$, and $30 \mathrm{~h}$ at $41^{\circ} \mathrm{C}^{(\mathrm{x})}$

\begin{tabular}{|c|c|c|c|c|c|c|c|}
\hline \multirow{2}{*}{ Sugar } & \multirow{2}{*}{ Strain } & \multicolumn{6}{|c|}{$\begin{array}{c}\text { Sugar concentration, } \mathrm{mg} / 100 \mathrm{~mL} \\
\text { Incubation time (h) }\end{array}$} \\
\hline & & 0 & 6 & 12 & 18 & 24 & 30 \\
\hline \multicolumn{8}{|l|}{ Raffinose } \\
\hline \multirow{4}{*}{81,5} & Lcr 098 & $3.79 \pm 0.64^{a}$ & $3.76 \pm 0.24^{a}$ & $3.20 \pm 0.12^{a}$ & $2.71 \pm 0.12^{\mathrm{a}}$ & $2.01 \pm 0.02^{\mathrm{a}}$ & $1.99 \pm 1.2^{\mathrm{a}}$ \\
\hline & $\begin{array}{l}\text { Lp } 025 \\
\text { Ldb }\end{array}$ & $3.79 \pm 0.64^{a}$ & $3.61 \pm 0.16^{b}$ & $2.51 \pm 0.15^{b}$ & $1.60 \pm 0.15^{\mathrm{b}}$ & $0.70 \pm 0.05^{\mathrm{b}}$ & $1.00 \pm 1.5^{b}$ \\
\hline & 045 & $3.79 \pm 0.64^{a}$ & $3.75 \pm 0.26^{a}$ & $3.25 \pm 0.17^{a}$ & $2.74 \pm 0.11^{c}$ & $2.04 \pm 0.07^{c}$ & $2.03 \pm 2.7^{\mathrm{C}}$ \\
\hline & St 001 & $3.79 \pm 0.64^{a}$ & $3.75 \pm 0.24^{a}$ & $3.13 \pm 0.12^{c}$ & $2.53 \pm 0.12^{d}$ & $1.59 \pm 0.02^{d}$ & $1.57 \pm 2.9^{d}$ \\
\hline 73 & Lpp 01 & $3.79 \pm 0.64^{a}$ & $3.74 \pm 0.14^{a}$ & $2.92 \pm 0.13^{c}$ & $1.83 \pm 0.13^{\mathrm{e}}$ & $1.03 \pm 0.03^{\mathrm{e}}$ & $1.52 \pm 3.8^{d}$ \\
\hline \multirow[t]{2}{*}{67} & Lpp235 & $3.79 \pm 0.64^{a}$ & $3.76 \pm 0.26^{a}$ & $3.17 \pm 0.16^{a}$ & $2.13 \pm 0.11^{f}$ & $1.25 \pm 0.16^{f}$ & $1.91 \pm 1.6^{\mathrm{a}}$ \\
\hline & Lcr 099 & $3.79 \pm 0.64^{a}$ & $3.76 \pm 0.24^{a}$ & $3.25 \pm 0.13^{a}$ & $2.85 \pm 0.08^{h}$ & $2.16 \pm 0.13^{\mathrm{e}}$ & $2.14 \pm 1.3^{\mathrm{e}}$ \\
\hline \multicolumn{8}{|c|}{ Stachyose } \\
\hline \multirow{4}{*}{78} & Lcr 098 & $6.17 \pm 0.78^{a}$ & $6.15 \pm 0.32^{\mathrm{a}}$ & $5.75 \pm 0.23^{a}$ & $5.14 \pm 0.03^{a}$ & $4.47 \pm 0.05^{\mathrm{bb}}$ & $4.45 \pm 0.03^{b b}$ \\
\hline & $\begin{array}{l}\text { Lp } 025 \\
\text { Ldb }\end{array}$ & $6.17 \pm 0.78^{a}$ & $6.01 \pm 0.35^{b}$ & $4.62 \pm 0.15^{b}$ & $2.78 \pm 0.01^{b}$ & $1.36 \pm 0.01^{\mathrm{bb}}$ & $0.79 \pm 0.01^{\mathrm{bb}}$ \\
\hline & 045 & $6.17 \pm 0.78^{a}$ & $6.14 \pm 0.46^{a}$ & $5.83 \pm 0.14^{a}$ & $5.15 \pm 0.12^{a}$ & $4.45 \pm 0.12^{b f}$ & $4.25 \pm 0.17^{b f}$ \\
\hline & St 001 & $6.17 \pm 0.78^{\mathrm{a}}$ & $6.14 \pm 0.37^{a}$ & $5.13 \pm 0.13^{c}$ & $4.12 \pm 0.26^{\mathrm{bg}}$ & $2.16 \pm 0.26^{b g}$ & $2.12 \pm 0.26^{b g}$ \\
\hline 72.5 & Lpp 01 & $6.17 \pm 0.78^{\mathrm{a}}$ & $6.13 \pm 0.27^{\mathrm{a}}$ & $4.93 \pm 0.17^{c}$ & $3.61 \pm 0.21^{b a}$ & $1.69 \pm 0.21^{\mathrm{ba}}$ & $1.56 \pm 0.21^{b a}$ \\
\hline \multirow[t]{2}{*}{66} & Lpp235 & $6.17 \pm 0.78^{\mathrm{a}}$ & $6.12 \pm 0.26^{a}$ & $5.09 \pm 0.13^{c}$ & $4.01 \pm 0.28^{b c}$ & $2.11 \pm 0.28^{b c}$ & $2.01 \pm 0.28^{b c}$ \\
\hline & Lcr 099 & $6.17 \pm 0.78^{a}$ & $6.14 \pm 0.33^{a}$ & $5.83 \pm 0.14^{a}$ & $5.76 \pm 0.15^{\mathrm{bd}}$ & $4.69 \pm 0.13^{b d}$ & $4.56 \pm 0.12^{b c}$ \\
\hline \multicolumn{8}{|l|}{ Glucose } \\
\hline & Lcr 098 & $20.1 \pm 1.45^{\mathrm{a}}$ & $17.2 \pm 1.24^{\mathrm{a}}$ & $13.6 \pm 0.44^{a}$ & $8.1 \pm 0.24^{a}$ & $3.42 \pm 0.03^{a}$ & $3.42 \pm 0.06^{a}$ \\
\hline & $\begin{array}{l}\text { Lp } 025 \\
\text { Ldb }\end{array}$ & $20.1 \pm 1.45^{\mathrm{a}}$ & $16.1 \pm 1.14^{b}$ & $11.6 \pm 0.45^{b}$ & $6.2 \pm 0.23^{b}$ & $1.82 \pm 0.05^{\mathrm{a}}$ & $1.82 \pm 0.04^{b}$ \\
\hline & 045 & $20.1 \pm 1.45^{\mathrm{a}}$ & $17.4 \pm 1.04^{\mathrm{a}}$ & $13.4 \pm 0.24^{\mathrm{a}}$ & $8.6 \pm 0.14^{c}$ & $3.82 \pm 0.11^{\mathrm{c}}$ & $3.82 \pm 0.09^{c}$ \\
\hline & St 001 & $20.1 \pm 1.45^{\mathrm{a}}$ & $17.5 \pm 1.05^{\mathrm{a}}$ & $13.6 \pm 0.45^{a}$ & $9.2 \pm 0.12^{d}$ & $4.42 \pm 0.12^{d}$ & $4.42 \pm 0.11^{d}$ \\
\hline & Lpp 01 & $20.1 \pm 1.45^{\mathrm{a}}$ & $17.2 \pm 1.11^{\mathrm{a}}$ & $13.2 \pm 0.34^{\mathrm{a}}$ & $8.5 \pm 0.13^{c}$ & $3.62 \pm 0.14^{\mathrm{a}}$ & $3.62 \pm 0.04^{a}$ \\
\hline & Lpp235 & $20.1 \pm 1.45^{\mathrm{a}}$ & $17.7 \pm 1.15^{\mathrm{a}}$ & $13.8 \pm 0.35^{a}$ & $9.6 \pm 0.13^{d}$ & $5.03 \pm 0.05^{\mathrm{e}}$ & $5.03 \pm 0.15^{\mathrm{e}}$ \\
\hline & Lcr 099 & $20.1 \pm 1.45^{\mathrm{a}}$ & $17.4 \pm 1.12^{\mathrm{a}}$ & $13.4 \pm 0.33^{a}$ & $8.7 \pm 0.05^{c}$ & $3.82 \pm 0.06^{c}$ & $3.82 \pm 0.10^{c}$ \\
\hline
\end{tabular}

Lp025=Lactobacillus plantarum pentosus SMN, 01, Lcr098=Lactobacillus casei subsp rhamnosus FNCC, 098, Lcr099= Lactobacillus casei subsp rhamnosus FNCC, 099, Ldb045=Lactobacillus delbrueckii subsp. bulgaricusi FNCC, 0045, Lp025=Lactobacillus plantarum SMN, 25, and Lpp235=Lactobacillus plantarum pentosus FNCC, 235, St001= Streptococcus thermofilus, 001

${ }^{(x)}$ From means \pm standard deviation of three duplicates for each sample.

${ }^{\text {abcdef }}$ Means in the same column for particular strains with different small letter superscripts are significantly different.

Significant when $\mathrm{P}<0.05$ 
Mal. J. Microbiol. Vol 4(2) 2008, pp. 26- 34

Table 4. Metabolic activity of investigated cultures during growth in soymilk for $0,6,12,18$, and $30 \mathrm{~h}$ at $41^{\circ} \mathrm{C}^{(\mathrm{x})}$

\begin{tabular}{|c|c|c|c|c|}
\hline Strain & $\begin{array}{l}\text { Incubation } \\
\text { time }\end{array}$ & $\mathrm{pH}$ & $\begin{array}{l}\text { Cell counts } \\
\text { (cfu/mL) }\end{array}$ & Lactic acid (mg/mL) \\
\hline \multirow[t]{6}{*}{ L. casei subsp rhamnosus FNCC, 098} & 0 & $6.4 \pm 0.14^{\mathrm{a}}$ & $6.8 \pm 0.02^{\mathrm{a}}$ & $0.2 \pm 0.01^{\mathrm{a}}$ \\
\hline & 6 & $6.2 \pm 0.11^{b}$ & $7.0 \pm 0.09^{b}$ & $0.3 \pm 0.01^{b}$ \\
\hline & 12 & $5.8 \pm 0.13^{c}$ & $7.6 \pm 0.11^{\mathrm{c}}$ & $0.5 \pm 0.03^{c}$ \\
\hline & 18 & $5.6 \pm 0.09^{d}$ & $8.0 \pm 0.05^{d}$ & $1.0 \pm 0.02^{d}$ \\
\hline & 24 & $4.8 \pm 0.09^{e}$ & $8.2 \pm 0.08^{\mathrm{e}}$ & $1.2 \pm 0.01^{\mathrm{e}}$ \\
\hline & 30 & $4.8 \pm 0.10^{\mathrm{e}}$ & $8.1 \pm 0.06^{e}$ & $1.2 \pm 0.02^{\mathrm{e}}$ \\
\hline \multirow[t]{6}{*}{ L. delbrueckii subsp. Delbrueckii FNCC, 045} & 0 & $6.4 \pm 0.14^{\mathrm{a}}$ & $6.8 \pm 0.02^{\mathrm{a}}$ & $0.2 \pm 0.01^{\mathrm{a}}$ \\
\hline & 6 & $6.1 \pm 0.09^{b}$ & $6.9 \pm 0.08^{\mathrm{a}}$ & $0.4 \pm 0.02^{b}$ \\
\hline & 12 & $5.6 \pm 0.12^{c}$ & $7.1 \pm 0.11^{\mathrm{b}}$ & $0.9 \pm 0.01^{\mathrm{c}}$ \\
\hline & 18 & $4.4 \pm 0.08^{d}$ & $7.6 \pm 0.09^{c}$ & $1.4 \pm 0.02^{d}$ \\
\hline & 24 & $4.0 \pm 0.08^{\mathrm{e}}$ & $8.2 \pm 0.08^{d}$ & $1.8 \pm 0.03^{\mathrm{e}}$ \\
\hline & 30 & $4.2 \pm 0.09^{d}$ & $7.6 \pm 0.08^{c}$ & $1.5 \pm 0.01^{d}$ \\
\hline \multirow[t]{6}{*}{ L. plantarum SMN, 25} & 0 & $6.4 \pm 0.14^{\mathrm{a}}$ & $6.8 \pm 0.02^{\mathrm{a}}$ & $0.2 \pm 0.01^{\mathrm{a}}$ \\
\hline & 6 & $6.2 \pm 0.13^{b}$ & $7.0 \pm 0.11^{b}$ & $0.3 \pm 0.03^{b}$ \\
\hline & 12 & $6.0 \pm 0.09^{c}$ & $7.5 \pm 0.10^{c}$ & $0.6 \pm 0.02^{c}$ \\
\hline & 18 & $5.7 \pm 0.11^{d}$ & $7.8 \pm 0.08^{d}$ & $1.1 \pm 0.01^{d}$ \\
\hline & 24 & $5.2 \pm 0.13^{\mathrm{e}}$ & $8.1 \pm 0.05^{\mathrm{e}}$ & $1.2 \pm 0.02^{\mathrm{e}}$ \\
\hline & 30 & $5.0 \pm 0.24^{\mathrm{e}}$ & $8.1 \pm 0.04^{e}$ & $1.2 \pm 0.01^{\mathrm{e}}$ \\
\hline \multirow[t]{6}{*}{ Streptococcus thermofilus, 001} & 0 & $6.4 \pm 0.14^{\mathrm{a}}$ & $6.8 \pm 0.02^{a}$ & $0.2 \pm 0.01^{\mathrm{a}}$ \\
\hline & 6 & $6.2 \pm 0.13^{b}$ & $6.9 \pm 0.12^{\mathrm{a}}$ & $0.3 \pm 0.03^{b}$ \\
\hline & 12 & $6.0 \pm 0.09^{c}$ & $7.3 \pm 0.06^{b}$ & $0.5 \pm 0.07^{c}$ \\
\hline & 18 & $5.6 \pm 0.11^{d}$ & $7.8 \pm 0.07^{\mathrm{C}}$ & $1.0 \pm 0.02^{d}$ \\
\hline & 24 & $4.8 \pm 0.13^{\mathrm{e}}$ & $8.3 \pm 0.06^{d}$ & $1.4 \pm 0.03^{\mathrm{e}}$ \\
\hline & 30 & $4.7 \pm 0.14^{\mathrm{e}}$ & $7.8 \pm 0.04^{e}$ & $1.3 \pm 0.11^{\mathrm{e}}$ \\
\hline \multirow[t]{6}{*}{ L. plantarum pentosus SMN, 01} & 0 & $6.4 \pm 0.14^{\mathrm{a}}$ & $6.8 \pm 0.02^{a}$ & $0.2 \pm 0.01^{\mathrm{a}}$ \\
\hline & 6 & $6.3 \pm 0.13^{a}$ & $7.4 \pm 0.01^{b}$ & $0.3 \pm 0.03^{\mathrm{a}}$ \\
\hline & 12 & $5.8 \pm 0.10^{b}$ & $7.9 \pm 0.08^{c}$ & $0.6 \pm 0.02^{b}$ \\
\hline & 18 & $5.2 \pm 0.09^{c}$ & $8.2 \pm 0.01^{d}$ & $1.4 \pm 0.02^{c}$ \\
\hline & 24 & $4.6 \pm 0.07^{d}$ & $8.8 \pm 0.05^{\mathrm{e}}$ & $1.6 \pm 0.01^{d}$ \\
\hline & 30 & $4.5 \pm 0.09^{d}$ & $8.6 \pm 0.04^{e}$ & $1.6 \pm 0.02^{d}$ \\
\hline \multirow[t]{6}{*}{ L. plantarum pentosus FNCC, 235} & 0 & $6.4 \pm 0.14^{\mathrm{a}}$ & $6.8 \pm 0.02^{\mathrm{a}}$ & $0.2 \pm 0.01^{\mathrm{a}}$ \\
\hline & 6 & $6.2 \pm 0.13^{b}$ & $7.0 \pm 0.11^{b}$ & $0.3 \pm 0.03^{\mathrm{a}}$ \\
\hline & 12 & $6.0 \pm 0.09^{c}$ & $7.5 \pm 0.10^{c}$ & $0.6 \pm 0.02^{b}$ \\
\hline & 18 & $5.7 \pm 0.11^{d}$ & $7.8 \pm 0.08^{d}$ & $1.1 \pm 0.01^{\mathrm{c}}$ \\
\hline & 24 & $5.2 \pm 0.13^{\mathrm{e}}$ & $8.1 \pm 0.05^{\mathrm{e}}$ & $1.2 \pm 0.02^{d}$ \\
\hline & 30 & $4.9 \pm 0.11^{\dagger}$ & $8.1 \pm 0.04^{e}$ & $1.2 \pm 0.01^{d}$ \\
\hline \multirow[t]{6}{*}{ L. casei subsp rhamnosus FNCC, 099} & 0 & $6.4 \pm 0.14^{\mathrm{a}}$ & $6.8 \pm 0.02^{a}$ & $0.2 \pm 0.01^{\mathrm{a}}$ \\
\hline & 6 & $6.2 \pm 0.11^{b}$ & $7.0 \pm 0.09^{b}$ & $0.3 \pm 0.01^{a}$ \\
\hline & 12 & $5.8 \pm 0.13^{c}$ & $7.4 \pm 0.11^{\mathrm{c}}$ & $0.5 \pm 0.03^{b}$ \\
\hline & 18 & $5.6 \pm 0.09^{d}$ & $7.8 \pm 0.05^{d}$ & $1.0 \pm 0.02^{c}$ \\
\hline & 24 & $4.8 \pm 0.09^{\mathrm{e}}$ & $8.0 \pm 0.08^{d}$ & $1.2 \pm 0.01^{d}$ \\
\hline & 30 & $4.8 \pm 0.10^{\mathrm{e}}$ & $8.1 \pm 0.06$ & $1.2 \pm 0.02^{d}$ \\
\hline
\end{tabular}

${ }^{\mathrm{x})}$ From means \pm standard deviation of three duplicates for each sample. ${ }^{\text {abcdef }}$ Means in the same column for particular strains with different small letter superscripts are significantly different. Significant when $\mathrm{P}<0.05$ 
reduced by Lactobacillus plantarum SMN, 25, $L$. plantarum pentosus SMN, 01 and L. plantarum pentosus FNCC, 235 after $24 \mathrm{~h}$ (Table 4).

\section{Viability of selected microorganisms and organic acids production in fermented soymilk}

In general, strains lactic acid Bacteria isolated from local fermented foods achieved the desired therapeutic level $\left(10^{8} \mathrm{cfu} / \mathrm{mL}\right)$ during growth by each organism in soymilk after $24 \mathrm{~h}$ of fermentation as shown in Table 3. Organic acid production, $\mathrm{pH}$ decline and other metabolic activities occurred during the first 12 to $24 \mathrm{~h}$ of incubation, which corresponded to the exponential phase of the growth. $L$. plantarum pentosus SMN, 01, L. plantarum SMN, 25, and L. plantarum pentosus FNCC, 235 exhibited better growth $(P<0.05)$ throughout the cultivation compared to other microorganisms. On the other hand, L. casei subsp rhamnosus FNCC, 098 L. casei subsp rhamnosus FNCC, 099, S. thermofilus, 001, and L. delbrueckii subsp. bulgaricus FNCC, 0045, showed slow growth by one log cycle lower $(P<0.05)$ than the rest of the organisms throughout the incubation. $S$. thermofilus, 001 grew better than $L$. casei subsp rhamnosus FNCC, 098 L. casei subsp rhamnosus FNCC, 099, and L. delbrueckii subsp. bulgaricus FNCC, 0045 and produced higher $(P<0.05)$ organic acid than the latter during fermentation. Wang et al. (1974) reported that L. delbrueckii ssp. bulgaricus grew poorly in soymilk because of their inability to ferment sucrose and other soy carbohydrates. Mital et al. (1974) also reported that certain organisms such as strains S. thermophilus, L. acidophilus, L. cellobiosis and L. plantarum, which utilized sucrose, grew well and produced large amounts of acid in soymilk. However contrary to our finding, the selected organisms used in this study produced lower amounts of organic acids in soymilk even though they grew well. Liu (1997) also reported that lactic acid bacteria grew well in soymilk but produce less organic acids. The low levels of organic acid concentrations in fermenting soymilk presumably encouraged cell growth and in other studies (Angeles and Marth, 1971; Kamaly, 1997; Liu, 1997). Furthermore, these selected strains possess $\alpha$-galactosidase (Table.2) and can utilize sucrose and other soy carbohydrates in soymilk as sources of energy, which enhanced better cell growth during $30 \mathrm{~h}$ fermentation at $42{ }^{\circ} \mathrm{C}$ (Mital et al., 1974; Liu, 1997). Although the organisms in our study showed a consistent increase in cell concentration from the start of incubation until $24 \mathrm{~h}$, the required $\mathrm{pH}$ of 4.5 was not reached within this time frame in comparison to the MRS medium with the exception of $L$. plantarum pentosus SMN, 01, L. plantarum SMN, 25, and $L$. plantarum pentosus FNCC 235 that showed a $\mathrm{pH}$ decline of 4.12. However, after a prolonged incubation for $30 \mathrm{~h}$, the $\mathrm{pH}$ of all batches declined to below 4.5. In general, the production of organic acids by all organisms in MRS was significantly higher $(P<0.05)$ than those produced in the fermented soymilk from 0 to $30 \mathrm{~h}$ (Table 4), thus making soymilk a potential medium for bacterial growth. Soymilk was reported previously as an appropriate growth medium for some lactic acid bacteria (Angeles and Marth, 1971; Kamaly, 1997; Liu, 1997).

\section{CONCLUSIONS}

Seven strains of lactic acid bacteria isolated from local fermented foods and added into soymilk during processing can degradation rafiinose and stachyose. Strains Lactobacillus plantarum pentosus SMN, 01, L. casei subsp rhamnosus FNCC, 098 L. casei subsp rhamnosus FNCC, 099, Streptococcus thermofilus, 001, Lactobacillus delbrueckii subsp. bulgaricus FNCC, 0045, L. plantarum SMN, 25, and L. plantarum pentosus FNCC 235 exhibited variable $\alpha$-galactosidase activity with $L$. plantarum SMN, 25 showing the highest activity in MRS supplemented media. However, all organisms reached the desired therapeutic level $\left(10^{8} \mathrm{cfu} / \mathrm{mL}\right)$ likely due to their ability to metabolize oligosaccharides during fermentation in soymilk at $41^{\circ} \mathrm{C}$. The oligosaccharide metabolism depended on a-galactosidase activity. $L$. plantarum SMN, 25, L. plantarum pentosus SMN, 01 and L. plantarum pentosus FNCC 235 reduced raffinose and stachyose by $81.5,73.0,67.0 \%$, and $78.0,72.5,66.0 \%$ respectively in soymilk.

\section{ACKNOWLEDGEMENTS}

The author would like to thank the Indonesian Institute of Sciences and the Centre for Food and Nutrition Studies, Gadjah Mada University for an excellent collaboration, and to Dr. Retno Indarti, MSc., Dr. Tyas Utami, MSc.and Prof. Ferry Sandra for helpful discussions.

\section{REFERENCES}

Albright, S. C., Winston, W. L. and Zappe, C. (1999). Data Analysis and Decision Making with Microsoft Excel. Pacific Grove, CA: Brooks/Cole Publishing Company.

Angeles, A. G. and Marth, E. H. (1971). Growth and activity of lactic acid bacteria in soymilk: Growth and acid production. Journal of Milk Food and Technology 34, 30 - 36.

Arai, S., Suzuky, H., Fujimake, M. and Sakurai, Y. (1996). Studies on flavour components in soybean.Part 2. Phenolic acids in defatted soybean flour. Agricultural and Biological Chemistry 30, 364 369.

Bordignon. J.R., Kazuhiko N., Tadashi Y. and Sayuki N. (2004). Hydrolysis of isoflavone and consumption oligosaccharides during lactic acid fermentation of soybean, Food and Technology Division, Japan International Research Center for Agricuture Sciences (JIRCAS ), Tsukuba, Ibaraki 305-8686, Japan (http:// www. Jircas.affrc.go.jp

Cheng, Y. J., Thompson, L. D. and Brittin, H. C. (1990). Sogurt, a yoghurt-like soybean product: development and properties. Journal of Food Science 55, 1178. 
Dave, R. I. and Shah, N. P. (1996). Evaluation of media for selective enumeration of Streptococcus thermophilus, Lactobacillus delbrueckii ssp. bulgaricus, Lactobacillus acidophilus, and bifidobacteria. Journal of Dairy Science 79, 1529 1536.

Davis, J. G., Ashton, T. R. and McCaskill, M. (1971). Enumeration and viability of Lactobacillus bulgaricus and Streptococcus thermophilus in yoghurt. Dairy Industries 36, 569 - 573.

Desai, A. R., Powell, I. B. and Shah, N. P. (2004). Survival and activity of probiotic Lactobacilli in skim milk containing prebiotics. Journal of Food Science $69,57-60$.

Desai, A., Small, D., McGill, A. E. J. and Shah, N. P. (2002). Metabolism of raffinose and stachyose in reconstituted skim milk and of n-hexanal and pentanal in soymilk by bifidobacteria. Bioscience and Microflora 21, 245 - 250.

Favaro Trindade, C. S., Terzi, S. C., Trugo, L. C., Della Modesta, R. C. and Couri, S. (2001). Development and sensory evaluation of soymilk based yoghurt. Archivos LatinoAmericanos De Nutricion 51, 100 104.

Garro M. S., Valdez G. F. D., Oliver, G. and Giori, G. S. D. (1998), Growth characteristics and fermentation products of Streptococcus salivarius subsp. thermophilus, $L$ casei and $L$. fermentum in soymilk, Z. Lebensm. Unters. Forsch. A 206, 72-75.

Garro M. S., De Giori, G. S., De Valdez, G. F. and Oliver, G. (1994). Utilization of soymilk galactosaccharides by lactobacilli, Microbiol.Alim. Nutr. 12, 61-66.

Garro M. S, Laura A. and Graciela S. d. G. (2005). Biological activity of Bifidobacterium longum in response to environmental $\mathrm{pH}$. Journal Applied Microbiology and Biotechnology 5, 70

Garro M. S, De Valdez, G. F., Oliver, G. and De Giori, G.S. (1999). Hydrolysis of soya milk oligosaccharides by Bifidobacterium longum CRL849, Z. Lebensm. Unters. Forsch. A 208, 57-59.

Kamaly, K. M. (1997). Bifidobacteria fermentation of soybean milk. Food Research International 30, 675 682.

Karleskind, D., Laye, I., Halpin, E. and Morr, C. V. (1991). Improving acid production in soybased yogurt by adding cheese whey proteins and mineral salts. Journal of Food Science 56, 999 - 1001.

Kurzer, M. S. (2000). Hormonal effects of soy isoflavones: studies in premenopausal and postmenopausal women. Journal of Nutrition 130, 660S-661S.

Laroia, S. and Martin J. H. (1991). Methods for enumerating and propagating bifidobacteria. Cultured Dairy Products Journal 32 - 33.

Lee, S. Y., Morr, C. V. and Seo, A. (1990). Comparison of milk-based and soymilk-based yoghurt. Journal of Food Science 55, 532 - 536.

Littell, R. C., Henry, P. R. and Ammerman, C. B. (1998). Statistical analysis of repeated measures data using SAS procedures. Journal of Animal Science 76, 1216-1231.

Liu, K. (1997). Soybeans: Chemistry technology and utilization. New York: Chapman and Hall. p 415-418.

Mital, B. K. and Steinkraus, K. H. (1975). Utilization of oligosaccharides by lactic acid bacteria during fermentation of soymilk. Journal of Food Science 40, $114-118$.

Mital, B. K., Steinkraus, K. H. and Naylor, H. B. (1974). Growth of lactic acid bacteria in soymilks. Journal of Food Science 39, 1018 - 1022.

Pinthong, R., Macrae, R. and Rothwell, J. (1980). The development of soya-based yoghurt. I Acid production by lactic acid bacteria. II Sensory evaluation and analysis of volatiles. Journal of Food and Technology 15, 647 - 659.

Omogbai B.A., Ikenebomeh M.J. and Ojeaburu S.I. (2005). Microbial utilization of stachyose in soymilk yogurt production, African Journal of Biotechnology, 4, $905-908$.

Ravula, R. R. and Shah, N. P. (1998). Selective enumeration of Lactobacillus casei from yoghurts and fermented milk drinks. Biotechnolology Techniques 12, 819 - 822.

Scalabrini, P., Rossi, M., Spettoli, P. and Matteuzzi, D. (1998). Charaterization of Bifidobacterium strains for use in soymilk fermentation. International Journal of Food Microbiology 39, 213 - 219.

Shah, N. P. (2000a). Some beneficial effects of probiotic bacteria. Bioscience and Microflora 19, 99 - 106.

Shah, N. P. (2000b). Probiotic bacteria: Selective enumeration and survival in dairy foods. Journal of Dairy Science 83, 894 - 907.

Sherkat, F., Nilsson, M., Eng, J. and Hadjis, M. (2001). Effect of processing on the isoflavones content of soy and soy-bovine milk products. Food Australia 53, $264-266$.

Shin, H. S., Lee, J. H., Pestka, J. J. and Ustunol, Z. (2000). Growth and viability of commercial Bifidobacterium spp. in skim milk containing oligosaccharides and inulin. Journal of Food Science $65,885-887$.

Tharmaraj, N. and Shah, N. P. (2003). Selective enumeration of Lactobacillus delbrueckii ssp. bulgaricus, Streptococcus thermophilus, Lactobacillus acidophilus, bifidobacteria, Lactobacillus casei, Lactobacillus rhamnosus and Propionibacteria. Journal of Dairy Science 86, 2288 $-2296$.

Tochikura, T., Sakai, K., Fujiyoshi, T., Tachiki, T. and Kumagai, H. (1986). p-Nitrophenyl glycosidehydrolysing activities in bifidobacteria and characterization of $\beta$-Dgalactosidase of Bifidobacterium longum 401. Agricultural Biology and Chemistry 50, $2279-2286$.

Tsangalis, D. and Shah, N. P. (2004). Metabolism of oligosaccharides and aldehydes and production of organic acids in soymilk by probiotic bifidobacteria. International Journal of Food Science and Technology 39, 1 - 14. 